\title{
Thoughts on Strengthening the Moral Construction of Higher Vocational Colleges under the New Situation
}

\author{
Wei Wei, FuXia Wang \\ Shandong Transport Vocational College, Weifang, Shandong, PR China (wfx2003sds@163.com)
}

\begin{abstract}
The twenty-first Century is the century of education, teachers are the key to education and cultivation of talents. The teacher takes the responsibility of training builders and successors for the socialist cause, improve the quality of the mission. In recent years, with the rapid development of higher vocational colleges, to strengthen the moral construction has become an important issue to be studied and resolved. This paper analyses the current situation of the teachers in higher vocational colleges. The corresponding countermeasures are put forward based on strengthening the moral construction of higher vocational colleges.
\end{abstract}

Keywords - Higher vocational colleges, Ethics construction, countermeasure, thinking

\section{新形势下加强高职院校师德建设的几点思考}

\author{
魏伟＼cjkstart王福霞 \\ 山东交通职业学院, 潍坊, 山东, 中国
}

\begin{abstract}
摘 要 21 世纪是教育的世纪, 搞好教育, 培养人才, 教师是关键。教师担负着培养社会主义事业建设者和接班人、提高民族素 质的使命。近年来随着高职院校迅速发展, 加强师德师风建设已成为高职教育工作中亟待研究和解决的重要课题。本文从当前高职院 校师德师风现状分析，提出了高职院校加强师风师德建设的相应对策，以供同仁商榷。
\end{abstract}

关键词 高职院校, 师德建设, 对策, 思考

1. 引言

百年大计，教育为本。我国的高职教育就是为国家和 地方经济发展培养适应生产、建设、管理、服务第一线需 要的技能型高素质人才，而高职院校的教师正担负着实现 培养人才的重任, 教师素质的高低直接影响着高职教育的 发展。因此, 加强师风师德建设已成为高职教育工作中函 待研究和解决的重要课题。加强高职院校师德建设, 是关 系到高职院校教育教学质量, 影响学生树立正确的世界观、 价值观和人生观的主要因素, 更是高职院校良好学风、师 风、校风形成的灵魂所在。在新形势下, 加强高职院校内 涵建设很重要方面是加强教师队伍的师德建设。

\section{2. 加强高职院校师德建设的意义}

2.1 加强师德师风建设是全面实施科教兴国战略和人才强 国战略的需要

随着经济全球化深入发展, 科技发展日新月异, 知识
越来越成为提高综合国力和国际竞争力的决定性因素，人 类社会正在步入一个以知识创新为助推器的 “知识经济时 代”。知识经济时代中, 人由于拥有了知识, 成为创造和获 取财富的根本，人才资源越来越成为推动经济社会发展的 战略性资源。

\section{2 加强师德建设是高职院校生存发展的必然需要}

教师队伍的素质, 不仅直接关系到一所大学的教学质 量和学术声誉, 也直接关系到其生存和长远发展。而师德 作为教师素质的核心, 更是关系到一所大学校园风气、学 术风气和社会声誉的好坏。“学高为师, 身正为范”, 良好 校园风气的形成, 离不开教师的率先垂范。良好的校园风 气是培养高素质学生必须的外在环境, 也是大学吸引学生 和家长, 得到社会认同的一个重要因素。 


\section{3. 高职院校师德师风的现状分析}

\section{1 教学工作中存在的师德建设问题}

圣人孔子在两千多年前就教诲我们: “仁者爱人”。作 为教师, “爱学生” 是最起码的师德。但是, 对于高职院校 的学生, 教师“要说爱你不容易”。这些学生从小学到中学 几乎都是“后进生”, 上课时他能说话、能睡觉、能玩手机、 能吃饭, 就是不能听教师讲课。教师每节课用于维持课堂 纪律的时间, 比起本科院校来要多数十倍。针对这种情况, 产生如下的师德问题:

（1）教师育人观念淡薄。满足于备好课、讲好课, 对学生中的厌学行为如上课打瞌睡、说话、逃课等现象, 采取“放任自流”的态度。多数教师采取“我认真讲课, 你爱 听不听” 的态度, “学生课堂上不注意听讲、不爱学习、课 下不做作业, 和我没关系。”

(2) 恨铁不成钢, 每节课必训学生, 训斥时不注意分 寸, 造成了对学生的心理伤害。比如, 有的教师课堂上说 学生是“高考筛出的渣子, 脑子有毛病”等等。试想, 高考 失利后无奈才到高职院校上学的学生, 本来就很自卑, 有 个别学生甚至是经过了三次高考的失利, 心灵深出的伤痛 本就难以愈合, 作为教师, 应该注意言语分寸。

(3) 把教学工作的目标定在应付考核上, 能不留作业, 就不留, 能少留作业的, 留了作业也不收回, 不批改, 或 叫学生批改。对于不交作业的学生, 也不给予批评教育, 缺乏作为教师应具备的敬业精神和最低的师德标准。

(4) 缺乏追求科学的进取精神, 长期不钻研业务, 对 本学科的前沿问题知之甚少, 观念陈旧知识贵乏, 教法呆 板, 甚至不会解析本专业的疑难问题。一只粉笔一本书, 几十年一个面孔，做一天和尚撞一天钟。

\section{2 科研工作中存在的师德问题}

(1) 撰写学术论文。为了评定技术职称才来写论文, 一旦职称问题解决了, 便不在考虑这个问题了, 论文也不 写了。近几年, 随着社会上学术刊物办刊产业化, 只要交 一定的版面费论文就能发表, 更加助长了论文的功利色彩。 有些论文毫无学术价值可言。

（2）科研课题的申请、批报、验收等工作不够规范, 存在着讲人情、走后门等不正之风。

(3) 编写教材。不管水平如何, 只要评定技术职称需 要, 都凑合在一起, 成立编写委员会, 买书号, 出教材。 出版的教材, 错误很多, 不但有文字、语法的错误, 还有 计算错误、理论错误。使用这样的教材教师首先要指导学 生先改错, 否则, 使用这样的教材, 只能误人子弟。同时, 这种教材的使用, 也给学生的学风建设树立了反面榜样。

\section{3 学生管理工作中存在的师德问题}

（1）学生管理工作中缺乏耐心细致的思想工作, 重学 生考试成绩, 轻学生优良品德养成; 重宿舍卫生内务成绩, 轻学生心理健康引导; 重学生对守则、规章制度条文的“遵 守”, 轻学生做“最好的自己”的培养和锻炼; 重学生管理工 作中对“消极不作为”的要求, 轻学生对突发事件, 危急情 况处理的能力的训练和提高等。

(2) 为了保证学生不出事, 学生的自习课只能按规定 在教室里学习, 大多数时间教室里纪律很难维持, 整个环 境不利于学生的学习。

(3) 对于学生谈恋爱的现象, 学生管理者大都缺乏积 极的引导。学生进入了高职院校学习, 特别是普通高中生 源的学生, 都进入了成年期, 谈恋爱是很正常的现象, 但 由于时代的关系, 他们缺乏正确的恋爱观、择偶观、婚姻 观, 不懂得含蓄、不懂得什么是责任、不懂得怎样进行必 要的自我保护, 总之在谈非常密切的异性朋友的过程中, 家庭、学校、社会从来就没有专门的人、专门的教材、专 门的授课时间给他们讲过相关的知识。作为学校的学生管 理工作者应该给他们及时地补上这一课。但在处理学生谈 恋爱这个问题上, 学生管理工作者几乎是走向了两个极端, 要么严格禁止谈恋爱, 学生由地上谈转入地下谈。要么就 是放任自流, 很少积极引导。

\section{4. 加强高职院校师德建设的对策}

4.1 完善师德建设组织体系的评价体系, 加强师德师风培 养

将师德师风建设纳入高职院校整体发展规划, 设立专 门的师德师风工作机构和稳定的工作人员, 完善师德师风 管理工作体系, 形成各部门通力合作, 齐抓共管的新局面。 高职院校师资管理工作体系中纳入师德培训, 使每位教师 都通过系统的职业培训, 才能从事具体的教学或管理工作。 充分发挥民主监督作用, 建立有效的师德评估指标体系, 加强和完善监督措施, 积极引入学生、家长和社会有关方 面对高职院校的师德建设进行监督和评价, 通过完善的师 德师风建设组织体系和评价体系为教师职业生涯创造良好 的工作环境和广阔的发展空间, 从根本上真正改变师德建 设工作在高职院校所处的弱势地位, 促使教师自觉加强自 身的职业道德修养, 从而形成高职院校良好的师德师风。

\section{2 加强师德师风建设, 注重引导和激励作用}

面对新形势, 高职院校要认识到师德师风建设对培养 人才质量的重要性, 结合校情积极引导广大教师做科学发 展观和社会主义核心价值观的践行者, 引导教师坚定教育 
信念, 体现爱岗敬业精神, 对高职院校的发展充满信心。 通过教育法规的正面引导作用, 组织教师认真学习《高等 教育法》、《教师法》、《职业教育法》等。在人才引进、职 称评定、职务晋升、评奖评优、学习进修等方面与师德的 考核与评价挂钩。对师德修养好、教学水平高、科研能力 强的教师要重点培养, 加大政策的倾向力度, 树立典型, 引导向模范学习。开展形式多样, 丰富多彩的师德教育活 动, 宣传师德风范和优秀事迹, 弘扬正气、激励先进、鞭 策落后, 积极引导广大教师逐步树立良好的职业道德。不 断夯实高职院校师德师风建设的重要载体, 让教师进一步 明确高职院校教师道德基本准则和依法从教的根本要求, 从而开创高职院校师德师风建设工作新局面。

\section{3 牢记学生为本, 教育为先的的教育理念, 提升师德师 风工作水平}

孔子说: “其身正, 不令则行。其身不正, 随令不行”, 由此可见, 提高教师自身的品德行为规范才能很好的引导 学生树立正确的世界观、人生观和价值观。教师在教书育 人的工作中, 应树立以学生为本, 教育为先的教育理念, 关心呵护学生成长, 鼓励学生进步, 尊重学生人格, 为学 生提供公平的教育坏境, 把弘扬爱国主义, 集体主义、社 会主义和改革创新的时代精神结合起来, 培养学生民族自 尊心、自信心和自豪感, 教育引导学生树立远大志向, 这 事把提升教师师德师风贯穿于整个教育教学过程中必不可 少的环节, 也是高职院校教育工作的重点。

4.4 搭建工作平台, 落实师德师风活动载体, 抓实师德师 风建设

抓实师德师风建设关键要善于搭建设工作平台, 落实 好活动载体, 把师德师风建设与教育教学等教师的工作生 活实际有机地结合起来, 出实招求实效。一是要认真制定 师德师风建设的长、中、短期计划, 尤其是中短期工作方 案, 要注重方案的预见性和针对性, 有组织分步骤地解决 师德师风建设存在的突出问题, 每年确定一个主题一个重 点, 并切实落实好开展工作的活动载体, 以增强师德师风 建设的实效性, 避免在师德师风建设上年年千篇一律, 流 于形式。二要因势利导开展好各类专项活动。积极开展 “师 德标兵评选” “师德师风建设演讲比赛”、 “师德师风知识讲 座” 等一系列活动, 增强教师师德修养意识, 提高教师职 业道德水平; 三要认真开展师德师风建设各类考核评比活 动, 奖优罚劣, 始终把握正确的师德师风建设方向。除了
认真抓好学校常规的师德师风建设考核评比以外, 还应创 新测评方式, 通过家长测评, 社会调查, 职工互评等全方 位、多角度地对教师在师德师风建设的情况进行综合评价。

\section{5 端正学术风气, 以良好学术氛围感染教师}

改革开放以来, 随着党和国家对教育事业的日益重视 和国民经济的发展, 高校教师的社会地位及工资待遇在不 断的提高。但眼下, 大多数教师的生活水平还较低, 与他 人的高额收入相比还存在较大的差异, 各种各样的诱惑每 时每刻都在 “进攻” 我们。正因为这样, 教师特殊的使命 才要求教师进行深层次的思想修养与职业道德修养, 自觉 地从中国传统文化与教育先贤的感人事迹中汲取精神营 养, 克制私欲膨胀, 摒弃拜金主义, 经受金钱考验。唯其 如此, 才能产生自觉的教育信仰, 矢志不渝地将教育作为 安身立命的终身行为, 固守教师那份高尚而纯真、淡雅而 清贫的精神生活; 才能义无反顾地以身立教, 甘为人梯、 无私地奉献终生于教育, 毕生追求无悔, 在喧哗中潜心研 究, 在浮躁中沉静思考, 在清贫中创造财富, 在平凡中铸 就伟大, 播下科学和文明的种子, 孵化未来和民族的希望。

\section{5. 结语}

综上所述, 加强师德建设, 不仅是国家发展、民族兴 旺的需要, 也是教师个人安身立命、获取幸福人生的需要。 在经济全球化、信息化的大环境中, 高职院校师德建设只 有与时俱进, 不断创新, 才能跟上时代发展的步伐。加强 教师的师德建设将有力保障和支持中国高等职业教育更快 更好地发展, 高职院校内涵建设才能取得成功。

\section{参考文献(References)}

[1] Opinions of the Ministry of education to further strengthen and improve the construction of teachers' Morality. Teacher [2005]1

[2] Liu Hong and Yang Shan, "Investigation and Reflection on the construction of ethics of teachers in Higher Vocational Colleges---Take Bayin Guoleng Vocational and Technical College as the example". Journal of Bayin Guoleng Vocational and Technical College, 2012.03.

[3] Shen Hua, "Analysis and Countermeasures of the ethics for teachers in Higher Vocational Colleges". Journal of occupation education.2009.10.

[4] Cha Fangneng, "Analysis on situation and Countermeasures of the construction of ethics of teachers in Higher Vocational Colleges". Occupation time magazine. 2008.12. 